\title{
Chinese-English subtitle translation from the Skopostheorie: A case study of the series of CCTV documentary "The Japanese Repatriation from the Huludao"
}

\author{
Dandan Chen \\ Department of Foreign Languages, Wuhan University of Technology Huaxia College, Wuhan, Hubei, China
}

\begin{abstract}
According to the theory of human action, Skopostheorie assigns the translation into the category of human communication activity with specific purposes. Therefore, subtitle translation, as one type of translation, also has its own purposes. The subtitle translation is characterized by instantaneity and popularity. Furthermore, the language of the subtitle translation must fulfill the high requirement in terms of logicality and artistic appeal. The translation in this paper, a work by the author, is an extract from the series of CCTV documentary "The Japanese Repatriation from the Huludao". Based on the principle that the purpose rules, the author did a careful analysis on the receivers' expectations, education background, and translation commissioner's requirements, etc.. The author also studied the language characteristics and the general translation strategies in the subtitle translation. In conclusion, the author comes up with the suitable translation strategies for this particular translation practice: naturalization, adding and omitting, logic combing and structure re-organizing, and choosing between styles.
\end{abstract}

Keywords: Skopostheorie; subtitle translation; "The Japanese Repatriation from the Huludao"

\section{INTRODUCTION}

As China is further opening up to the world, more and more foreign movies and television programs gain their entry into the country. Simultaneously, the Chinese movies and TV productions also make their way into foreign markets. So subtitle translation has gained increasing popularity in recent years. Based on a case study of the series of CCTV documentary "The Japanese Repatriation from the Huludao", the aim of this paper is to discuss the guiding significance of the Skopostheorie in subtitle translation. "The Japanese Repatriation from the Huludao" is a series of CCTV documentary recording a historical period after WWII when numerous Japanese immigrants, who were leading wandering lives in China, tried to run all the way back to Japan. In translating the subtitle of this documentary, the author encountered some difficulties: first, for foreign audiences who lack background knowledge of this event, they are unfamiliar with the content of this documentary; second, due to the content related to cultural differences, a

*Corresponding author: 215880250@qq.com bridge need to be built to narrow the gap between different cultures; third, as many colloquial expressions and dialects may appear in field interviews in the documentary, sometimes the language tend to be loose and difficult to understand. In the process of solving these problems, the author makes use of the theoretical framework of Hans J. Vermeer's skopos theory in order to come up with some reliable ways to choose translation strategies for subtitle translation.

Inheriting some thoughts from Katharina Reiss, Vermeer got rid of the theory of equivalence centering the source language, prioritized the purpose of source text and created the Skopostheorie which is based on Mantarri's theory of translation action. He also broke the conventions, listed the purpose of text as one of the translation strategies and started observing translation in terms of Action theory and Intercultural Communication. Scholars of the Skopostheorie think translation is a specific activity not a way of decoding. As every activity has a purpose, translation is regulated by purpose. Without sorting out the purpose of translation at the very beginning, one could hardly translate any source language (Tan Zaixi, 2004, p.255). 
According to skopos theory, it is implied that translation serves specific "receiver" to meet specific needs in specific environments. Consequently, as for principle of translation, the primal principle should be purpose principle that the purpose of translation determines the process of translation and the measures used to translate (Tan Zaixi, 2004, p.256). As a result, the purpose determines the translation strategy. As long as the purpose of translation can be realized, literal translation, paraphrasing or the way combining both of the two ways is feasible.

\section{CASE ANALYSIS}

The Documentary "The Japanese Repatriation from the Huludao" introduces how Chinese government selflessly helped the Japanese immigrants abandoned by Japanese government after they failed to conquer China find their way home. The purpose of this documentary is to inform the westerners of this historical period. The reason why they choose to watch this documentary is probably they want to learn about history of China. So I suppose the western audiences have accepted secondary education. Compared to Chinese people who have no difficulty in understanding the main massages conveyed by the documentary, the western audiences probably find the documentary difficult to understand because they lack relevant background information. To enable western audience to comprehend this documentary well, we must realize the characteristics of subtitle translation and the translation strategies.

There are two characteristics of subtitle translation: one is instantaneity. Instantaneity means audiences cannot reread the subtitles, ruminating over the subtitles (Zhang bochun, 1998, p.50-53); the other is popularity. Generally speaking, movies and TV dramas are usually enjoyed by ordinary audiences. So the languages of subtitle translation should feature colloquial expressions and popular words (Meng Xiance, 2007, p.150-151). It is universally acknowledged that the language of the subtitle translation must fulfill the high requirements in terms of logicality and artistic appeal.

When translating the Documentary "The Japanese Repatriation from the Huludao", the author carefully chose four strategies according to Hans J. Vermeer's skopos theory. The following examples are extracted from the subtitle translation of this documentary and given to demonstrate a concrete application of skopos theory.

\subsection{Domestication translation strategy}

Example 1:

Source language: 请你在地下放心。

Translation: May you stay at rest.
Example 2:

Source language: 如果你地下有灵, 也能给我们一 点帮助的话, 那就拜托了。

Translation: We are trying our best to do that. If you can hear me in Heaven, please give us a little help.

Analysis: Three principles of skopos theory are Skopos Rule, Coherence Rule and Fidelity Rule. In fact the Coherence Rule and Fidelity Rule refer to intra-textual coherence and inter-textual coherence respectively. Intra-textual coherence means the information and scenes in source language can appear in audiences' mind. That is to say "the translation must make sense in specific cultural and interpersonal environments of the target language" (Bian Jianhua, 2008, p.32). Fidelity does not mean translation must be loyal to the source language but means there is a kind of close relationship between both of them. In these three principles, Coherence Rule and Fidelity Rule are subordinate to Skopos Rule. Fidelity Rule is subordinate to Coherence Rule (Nord, 2001, p.91). In this case, when the woman mentioned her husband who had died, she used two phrase, “地下放心” and “地下有灵”. In western culture, it is believed that people go to heaven after they die. According to Coherence Rule, in the first example, the author omitted “地下” and directly translated “放心”, the central idea. In the second example, the author translated “地下” into "in heaven". The two source sentences are used to express the feelings of the speakers not to introduce the religious differences between the west and the east So domestication translation strategy is adopted to translate these two sentences to clear the obstacles to westerners' understanding of this documentary.

\section{Example 3:}

Source language: 这是一份日本政府 1932 年的文 档档案。内容是当时的内阁批准成立满洲拓植 公社。

Translation: This is a 1932 Japanese government file archive. It is about the Cabinet's approval of the establishment of the government tasked with developing Manchuria.

Example 4:

Source language: 进了屋里面就是炕, 炕只有一块 席子大小。

Translation: In the room, you could only find a heatable brick bed, the size of a mat.

Analysis: According to Vermeer, a real translation should be like an intercultural activity (Bian Jianhua, 2008, p.83). In example 3 and 4, “满洲拓植公社” and “炕” are cultural proper names in Chinese. There are no counterparts in English. So, when translating, the author explained the two Chinese proper names in detail according to domestication translation strategy, explaining the underlying meaning of them. Conse- 
quently, the two cultural Chinese proper names were translated into "the organization tasked with developing Manchuria" and "a heatable brick bed". In this way, the westerners can understand the subtitle without having footnotes.

\section{Example 5:}

Source language: 仅仅统计，1940 年5月至 1940 年的 8 月这三个月，当时日侨俘的开资就达到 1.4 亿元, 其中用吃饭伙食费的开销就达到 1.2 亿元，当时东北的流通券。

Translation: In the three months from May to $\mathrm{Au}-$ gust 1946 alone, 140 million Yuan of the kind then in use in Northeast China was spent on the Japanese, including 120 million Yuan on food alone.

\section{Example 6:}

Source language: 在葫芦岛的龙湾公园里, 有一座 “恩”字碑。

Translation: In the Longwan Garden in Huludao, there is a monument carved with the Chinese character meaning "gratitude".

Analysis: In example 5 and 6, “东北流通卷” and “恩” 字碑 are cultural proper names in Chinese. So, the author translated the two Chinese proper names into "Yuan of the kind then in use in Northern China" and "a monument carved with the Chinese character meaning gratitude". As subtitle translation features conciseness, footnotes and cultural background which are indispensable literal translation are not necessary for subtitle translation. The purpose of subtitle translation is not to transmit historical knowledge but eliminate obstacles to watching TV in foreign languages.

\subsection{Addition and subtraction}

Example 7:

Source language: 我的父母亲他们没有忘记那个 地方, 我们也绝不能忘记。

Translation: My parents never forget that place, and neither will we.

\section{Example 8:}

Source language: 那么, 在 60 年前, 在中国东北 的大地上, 围绕着一个港口, 究竟发生了什么 样的故事, 又是什么样的历史让那些归国的日 本侨民刻骨铭心、念念不忘。。。。。。

Translation: So, what exactly happened 60 years ago around this port in Northern China that the repatriated Javanese remember forever with such deep gratitude?

Analysis: The Chinese language features aesthetic tonality, symmetry and repetition. However, in subtitle translation, too much repetition is unnecessary. Furthermore, due to the limitation of time and space, some repetition cannot be realized. The Chinese sen- tences given above comprise some repeated words. In example 7, the author adopted typical English sentence patterns to eliminate unnecessary repetition. In example 8, on the semantic level, “什么样的故事” equals “怎样的经历” and “刻骨铭心” equals “念念 不忘”. Such kind of repetition sounds very catchy and impressive in Chinese language. However, in translation, the author exercised only two phrases, "what happened" and "gratitude" to avoid repetition, stressing the conciseness of English language. Meanwhile, considering the principle of Fidelity rule, two adverbs, "exactly" and "deep", were added to the target sentences.

\section{Example 9:}

Source language: 为了影片的拍摄, 他们又回到了 东北, 回到了葫芦岛, 回到了 60 年前那场充 满艰辛困苦、雪雨风霜、也充满中国人宽容人 道的大遣返。

Translation: The couple went back to Huludao in Northeast China to make the film. Huludao revived their memories of repatriation 60 years ago, a memory of hardship and brutality, and a memory of the warmth and humanity of the Chinese people.

Analysis: The Chinese consists of parallelism sentences with long attributive. First of all, the author divided the Chinese into two sentences, translating the first sentence according to the sequence and adding a new subject to the second sentence. Because the Chinese aims to stress the details of the history about “葫 芦岛” and “大遣返”. In the second sentence, the author chose “葫芦岛” as the subject and added “memories" as the object of "revive". Then, another "memory" which was used as an appositive further explained the content of the memory of “葫芦岛” and “大遣返”. If memories were not added and the sentence was translated as "they went back to the repatriation 60 years ago, full of hardship and brutality, warmth and humanity of the Chinese people" , the translation is likely to seem lengthy, loose and short of logic.

\subsection{Logical combing and structural adjustment}

Example 10:

Source language: 一九二七年六月, 刚出任日本国 首相不久的原日本政友会总裁、陆军大将田中 义一召开了一次名为“东风会议”的内阁会。

Translation: Senior Army General Tanaka Giichi was the former president of Rikken Seiyükai, one of the main political parties in pre-war Japan. In June 1927, shortly after taking office as Prime Minister, Tanaka Giichi held a Cabinet meeting called the "Far East Conference."

Example 11: 
Source language: 在苏军从东北的各个方面怒涛 般的进攻下，日本关东军苦心经营十几年的坚 强工事，仅仅 3 天便被全面摧毁。

Translation: The Japanese had painstakingly built up this fortification over the previous ten years. However, the Soviet Army drove straight China from all direction, crashing down the strong fortification in just three days.

Analysis: Composed of several clauses, example 10 and 11 are long sentences full of a large amount of information. According to skopos theory, target audience is an essential factor to take into account when translating. It is estimated that the reason why Western audience watch this documentary is to learn about the history of China rather than do a "reading comprehension". So overlong subtitles may make it difficult for western audiences to understand the content of the documentary and disengage them from watching it. Consequently, the author first exacted the key information from the two Chinese sentences and then paraphrased the each Chinese sentence and divided each of them into several separate sentences to translate according to thought groups and the images on screen. In the example 10, the long Chinese sentence was divided to two short sentences. Specifically speaking, the author used a short sentence introducing the personal background of Tanaka Giichi at the very beginning. Then the author transformed the attributive, “刚 出任日本首相不久的”, into the adverbial of time to explain the main clause. In the eleventh example, the author similarly divided the long Chinese sentence into two parts. What the Japanese military did and what the Soviet military did were elaborated in two sentences respectively. In the first sentence, the modifier-noun phrase, “日本关东军苦心经营十几年的坚 强工事” was transformed into a sentence with the subject, “日军”. In the second sentence, “在苏军从东 北的各个方面怒涛般的进攻下”was translated into a sentence with the subject, “苏军”. The strategy, logical combing and structural adjustment, accord to the Coherence Rule.

\section{Example 12:}

Source language: 在辽宁葫芦岛的海边有一座用 花岗岩打造的纪念碑, 在隔海相望的日本九州 的佐世保港, 也真立着一座纪念碑, 碑石用日 本非常普遍的角砾凝灰岩制成。

Translation: On the seashore at Huludao, Liaoning Province, a granite monument rises up. Across the sea at Sasebo Port, Kyushu, Japan, stands another monument. The monument in Sasebo is made of tuff breccia, a kind of rock commonly found in Japan.

Analysis: As the Chinese is long, it was divided into three dependent sentences in terms of thought group in order to facilitate the subtitle broadcasting and the audiences' understanding of the subtitle. In Chinese, the attribute is regularly placed in front of the nouns. In comparison, the position of attribute is very flexible. So when translating Chinese into English, the translators have more options about where to put the attribute In this example, the author transformed “日本非常普 遍的”, the pre-attributive in the third sentence, into "commonly found in Japan", the post-positive attributive to modify the added appositive, "a kind of rock", of "stuff breccia".

\section{Example 13:}

Source language: 地震过后, 惊魂甫定的日本决策 层愈发感到了国土面积狭小、人口稠密和地质 构造上的不安全。

Translation: After the earthquake, those in power, who just recovered from the shock themselves, became increasingly alarmed at the lack of safety caused by Japan's small territorial area, dense population and unstable geographical structure.

Analysis: In this example, the Chinese consists of several attributives to modify “不安全”. According to the Coherence rule, the translation must correspond with the language habits of westerners and is able to transmit some messages in target environments. So when translating, translators should think carefully and properly make some slight changes to the source language to ensure the westerners can well understand the subtitle they see. In the Chinese sentence, “国土面 积狭小、人口稠密和地质构造上的” are used to modify “不安全”. If the Chinese attributives were translated as "the lack of safety of Japan's small territorial area, dense population and unstable geographic structure", this translation might sound wired and cannot meet the expectations of the audiences. In dealing with this kind of attributives, the author added a word "caused", using a non-predicate verb to unveil the logical relation between the two phrases. “惊魂未 定的”, another attributive, was transformed into a verb, which indicates the flexibility of English language.

\subsection{Selections between different styles}

Example 14:

Source language: 沿着山道, 树林里的小道, 搁哪 儿过来了。下大雨, 又泥泞, 又没吃的, 走了 好几天。路上还有死的, 小孩还有扔的。实在 走不动, 就把小孩拿起来搁地下了。就搁被蹬 出来了, 叫欧吉桑, 欧吉桑。找他妈妈, 谁管 呀! 把头转过去就走了。中国人, 现在是谁我 也知道这人, 到这看看是小孩, 捡回去了。中 国人捡的不在少数。

Translation: From there they walked along the mountain path and crossed the tracks in the woods. It was pouring, and they walked for days on the muddy path, hungry and tired. Scattered 
along the paths were dead people and abandoned children. When they were too exhausted, parents just left their children by the path. No one paid attention to the children screaming. "Mom! Mom!" They just continued without looking back. The Chinese, I don't know who by name, went to take the children back home. A lot of Chinese people came to pick up the children.

Analysis: The comments which sound loose and illogical were given in an interview in the documentary by an old Chinese peasant who is under-educated. Considering that this is a documentary which aims to introduce Chinese history, the author adopted formal written language to translate the informal spoken language, which makes the translation sounds more explicit and clear. This strategy, selections between different styles, conforms to skopos theory and Coherence rule.

\section{CONCLUSION}

In this essay, according to the framework of the skopos theory, the author analyzes the anticipation of the target audiences, their education and cultural background and the requirements of the initiator of translation, extracts the useful information from the drafts of subtitle translation, and conclude that in this case the most suitable translation strategies are domestication translation strategy, addition and subtraction, logical combing and structural adjustment, and selections between different styles to ensure the western audiences a good understanding of this documentary and some basic historical knowledge about China.

However, when writing this essay, the author also realized some problems. First of all, the supreme principle of the skopos theory is purpose principle. According to purpose principle, after considering the purpose of translation and the target audiences and selecting the most suitable translation strategies, the translator can start translating by exacting useful information from the source language which is regarded as a information provider. But this could mean that the skopos theory can decrease the status of source language. As a result, the translator may be at a risk of overlooking the significance of the source language and translating the source language at random. As a matter of fact, in many translating practices, the author sacrificed the Fidelity rule. Second, because the examples were extracted from the same documentary, the subject of each sentence is monotonous and seems not typical and representative. Finally, I hope this essay can provide some help to documentary translators to some degree in the future.

\section{REFERENCES}

[1] Nord, Christiane. 2001. Translation as a Purposeful Activity: Functionalist Approaches Explained. Shanghai: Shanghai Foreign Language Education Press.

[2] Bian Jianhua. 2008. Study on Functional Skopos Theory of Translation: Inheritance and Transcendence. Beijing: China Social Science Press.

[3] Meng Xiance. 2007. Film and television dialogue translation under the guidance of skopos theory. Journal of Yunnan Finance and Economics University (Social Science Edition).

[4] Tan Zaixi. 2004. A Short History of Translation in the West. Beijing: The Commercial Press.

[5] Zhang Bochun. 1998. On the film translation. Chinese Translators Journal. 